\title{
Resenha
}

\section{Resenha: livro Inside Terrorism de Bruce Hoffman}

Marina Cavalcante Martins Pereira ${ }^{1}$

DOI: $10.5752 / P .1809-6182.2020 \mathrm{v} 17 \mathrm{n} 2 \mathrm{p} 64$

Recebido em: 04 de maio de 2020 Aceito em: 18 de maio de 2020

Inside Terrorism, tem como um de seus objetivos ser acessível, como algo que possa ser entendido tanto por acadêmicos como por leigos. Com dez capítulos e uma conclusão ao final de cada um o livro conta com uma série de detalhes e exemplos que ajudam o leitor a formar uma ampla visão e consolidar seu entendimento do assunto.

No primeiro capítulo, Hoffman busca definir e entender o que é o terrorismo. Ele o define como sendo um fenômeno essencialmente político que faz uso da violência para alcançar objetivos políticos, calculado e planejado, ou seja, um ato sistemático e que visa à busca, à aquisição e ao uso de poder para alcançar mudanças políticas.

A frequente mudança do termo terrorismo, ao longo dos anos, causou, segundo Hoffman, certa dificuldade quando se pensa em sua definição. No segundo capítulo ele trata do fim do império e as origens do terrorismo contemporâneo, abordando pontos como: a guerra na Palestina, as lutas anticoloniais da década de 1950, em especial casos como Chipre e Argélia e como insurreiçôes etno-nacionalistas, subsequentes à Segunda Guerra Mundial, tiveram uma influência duradoura nas campanhas terroristas posteriores.

No terceiro capítulo o autor passa a analisar como se constitui a internacionalização do terrorismo. Ele aponta para dois fatores fundamentais. Primeiro, a forte influência que Organização de Libertação da Palestina (OLP) exerceu neste aspecto, e, segundo, o evento terrorista protagonizado pela mesma organização que marcou a história do terrorismo internacional e serviu como inspiração para outras organizaçóes terroristas, o ataque aos atletas israelenses nos Jogos Olímpicos de Munique em 1972.

Segundo Hoffman, quando pensamos sobre terrorismo, não apenas motivos políticos baseiam as causas dos terroristas, mas sim, também, o imperativo religioso, que se tornou a característica definidora mais importante de tais grupos. Esta temática é trabalhada no capítulo quatro e a discussão leva ao capítulo seguinte que fala sobre terrorismo suicida onde esse gênero de ataque terrorista tem se tornado cada vez mais frequente e escolhido devido a suas vantagens táticas, sua alta eficiência em atingir os objetivos, seus baixos custos e maior

\footnotetext{
1 Mestranda em Ciência Política e Relaçôes Internacionais pela Universidade Federal da Paraíba (PPGCPRI/UFPB). Contato: marinacavalcante@outlook.com. ORCID: https://orcid.org/0000-0003-3764-6828.
} 
facilidade de operacionalizar. O uso dessa técnica, ao contrário do que muitos possam pensar, não é algo decidido de forma irracional ou desesperada pelos terroristas, é, na verdade, uma escolha inteiramente racional e calculada.

Essa é uma característica que todos os grupos terroristas, motivados por diversas razôes, têm em comum: seus atos nunca são aleatórios ou sem sentido. Além disso, todos eles desejam buscar, com suas ações, o máximo de publicidade e intimidação possível para assim conseguir atingir seus objetivos. Desta forma, Hoffman aponta nos capítulos seis e sete como os terroristas fizeram e fazem uso da mídia e opiniôes públicas, moldando assim, a opiniāo global sobre esta questão.

"Claramente, o terrorismo e a mídia ainda permanecem unidos em uma relação inerentemente simbiótica, cada um se alimentando e explorando o outro para seus próprios propósitos” (HOFFMAN, 2017, p. 233, tradução nossa). Muitos criticam a mídia por cobrirem de forma, às vezes, tão intensa tais eventos e temem que tal exposição possa atrair mais pessoas simpatizantes a essas causas, estimulando-as e, consequentemente, fazendo com que determinadas organizaçôes terroristas cresçam. Hoffman mostra, porém, que nos anos 1980 o impacto que tais notícias causaram no público em geral e na opinião pública é o de repulsa a tais atos, mas, por outro lado, eles demonstravam um profundo fascínio por esses eventos.

O século XXI conta com uma maior sofisticação dos meios de comunicação dos grupos terroristas e isso vem, principalmente, do grande avanço tecnológico visto nos últimos anos. Hoffman aponta, em seu oitavo capítulo, para o fato de como grupos terroristas como ISIS (Islamic State of Iraq and Syria) e Hezbollah têm usado esse avanço em seus meios de comunicação para criar propagandas que disseminam seus ideias e razôes de lutas para, assim, atrair possivelmente novos membros e simpatizantes das causas.

Outro assunto relevante ao se pensar terrorismo é a questão sobre seus mind-sets. Como já mencionado anteriormente, os atos terroristas são geralmente premeditados e planejados de forma cuidadosa, sendo assim, as táticas escolhidas pelos grupos, os alvos, armas, dinâmica organizacional internas e as personalidades de seus membros-chaves são sempre moldadas pela ideologia do grupo. Independente da técnica utilizada ou das suas motivaçóes, todos os grupos terroristas possuem uma característica em comum - eles vivem no futuro, ou seja, naquele momento distante no qual triunfarão sobre seus inimigos e alcançarão a realização dos seus objetivos políticos. Para isso, é fundamental que tais grupos tentem se manter um passo à frente das autoridades e das tecnologias de contraterrorismo.

Por fim, em seus dois últimos capítulos, Hoffman levanta algumas preocupações em relação ao terrorismo moderno. Uma delas é o uso que Estados fazem do terrorismo como uma arma e instrumento de política externa. Ele expressa que a partir dos anos 1980, alguns governos adotaram o terrorismo como um instrumento deliberado de política externa.

Outra preocupação apontada pelo autor é a atração, cada vez maior, que os grupos terroristas têm mostrado pelas QBRN (armas químicas, biológicas, radiológicas e nucleares). Há grupos que tentam desenvolver capacidades que abrangem todas as quatro categorias de armas e há, ainda, aqueles que são atraídos por algumas dessas armas em específico devido sua potencial letalidade. Ele aponta que os terroristas mostravam uma tendência em ser mais hesitantes 
quanto a tirar proveito de novas situaçóes, embora vários grupos terroristas tenham supostamente cogitado a ideia de usar armas letais indiscriminadamente, ninguém ultrapassou este limiar crítico. Porém, nos últimos anos, tem-se observado uma maior facilidade de acesso às informações e a materiais necessários para fabricar e empregar armas QBRN e isso poderia favorecer uma nova era de terrorismo ainda mais sangrenta e destrutiva.

O objetivo principal de Hoffman ao escrever esta obra era o de preencher um vazio dentro da literatura sobre terrorismo. Neste livro, ele busca abordar todos os aspectos dentro desta temática. Ele vai desde o início, definindo terrorismo, até como este se apresenta no mundo atualmente. $\mathrm{O}$ autor aponta, então, para o fato de que o combate ao terrorismo é como tirar uma série de fotos dentro de um lapso de tempo, onde a imagem que se tira hoje não é a mesma de ontem e não será a mesma amanhã. O terrorismo está em constante mudança e evolução e cabe aos Estados tentar estar sempre um passo à frente.

\section{REFERÊNCIA}

HOFFMAN, Bruce. Inside Terrorism. New York: Columbia University Press. Third Edition. 2017. ISBN 978-0-23154489-4. 